\title{
When your child with epilepsy die suddenly: febrile seizures are part of the process?
}

\author{
Vera C. Terra', Hélio R. Machado', Américo C. Sakamoto', \\ Ricardo M. Arida², Fulvio A. Scorza ${ }^{3}$
}

\begin{abstract}
Febrile seizures (FS) affect almost 2-5\% of children and factors related to an increase susceptibility of children to FS may involve an imbalance of inflammatory cytokines and genetic factors. FS had low morbidity, but may be associated with the occurrence of late chronic epilepsy. Here we describe factors related to FS and its possible correlation with SUDEP.

Key words: epilepsy, sudden death, febrile seizures.
\end{abstract}

Quando seu filho com epilepsia morre subitamente: crises febris fazem parte do processo?

\section{RESUMO}

Crises febris (CF) afetam aproximadamente 2-5\% das crianças e os fatores envolvidos com essa maior susceptibilidade das crianças às $\mathrm{CF}$ podem estar relacionados com uma ação inadequada de citocinas inflamatórias, além de fatores genéticos. As CF têm baixa morbidade, mas podem estar associadas à ocorrência de epilepsia crônica. Nós discutiremos os fatores relacionados com CF, considerando-se sua possível associação com SUDEP.

Palavras-chave: epilepsia, morte súbita, crises febris.

\section{Correspondence \\ Vera Cristina Terra \\ Department of Neurology / CIREP \\ Campus Universitário \\ 14048-900 Ribeirão Preto SP - Brasil \\ E mail:v.c.terra@rnp.fmrp.usp.br \\ Support \\ This work was supported by FAPESP/ CNPq/MCT-Instituto Nacional de Neurociência Translacional, CNPq, CAPES, FAPESP-CInAPCe, and FAEPA}

Received 6 December 2010 Received in final form 15 December 2010 Accepted 23 December 2010
Febrile seizures (FS) affect almost 2-5\% of children ${ }^{1}$ and are defined as a seizure, occurring in a child after 1 month of age associated with a febrile illness not induced by an infection of the central nervous system (CNS), without previous neonatal seizures, a previous unprovoked seizure or an acute symptomatic seizure ${ }^{2}$. Factors related to an increase susceptibility of children to FS are not totally enlightened and are probable multifactorial. Some authors had reported an imbalance of inflammatory cytokines, specially an increased production of interleukin $1 \beta$ that have a proconvulsivant effect in patients with $\mathrm{FS}^{3}$. Also, the high prevalence of family history of FS and occurrence of FS in homozygous twins suggest that genetic factors may play an important role in
FS events ${ }^{3}$. Usually, FS had low morbidity and deaths directly related do these seizures had not been reported, except when considering febrile status epilepticus ${ }^{4}$.

The main morbidity related to FS is the development of long term epilepsy reported with a variable incidence risk that may be as low as $0.1 \%$ and as high as $44 \%$ of the patients, with a mean risk of $5.8 \%$ of the cases ${ }^{4}$. Evidences from epidemiological studies suggest that approximately $25 \%$ of the patients with epilepsy evolve with medically intractable seizures, with a major proportion of patients in the pediatric group ${ }^{5}$. Unfortunately, individuals with epilepsy are at a higher risk of death than those from the general population and each year, about 1:500 to 1:1000 patients with chronic epilepsy will die sud- 
denly, suffering of sudden unexpected death in epilepsy (SUDEP) $)^{6}$. SUDEP is defined as a death that occurred suddenly, unexpectedly and of non-traumatic and nondrawing, witnessed or unwitnessed, with or without the evidence of a seizure, excluding status epilepticus, and without a toxicological or anatomical cause of death in post-mortem examination ${ }^{7,8}$ and will be responsible for about 7.5 to $17 \%$ of all deaths in epilepsy ${ }^{9}$. Individuals with epilepsy are at a higher risk to suffer of SUDEP. Although there was no suggestion in the literature that FS were related to SUDEP ${ }^{1,4}$ there is a significant association of refractory epilepsy and a history of FS ${ }^{10-12}$. Risk factors possible associated with SUDEP are refractoriness of the epilepsy, occurrence of generalized tonic-clonic seizures, antiepileptic drugs polytherapy, early age of epilepsy onset, long term seizure disorder (more than 15 years), winter temperatures ${ }^{13}$, cardiovascular and pulmonary abnormalities ${ }^{14}$ and genetic factors ${ }^{15}$.

Cardiac mechanisms may have a main role in SUDEP occurrence and repetitive cardiac damage and arrhythmias during seizures may induce autonomic imbalances with sympathetic stimulation and the development of fatal arrhythmias ${ }^{16,17}$. In accordance to this, post-mortem examinations in people that died of SUDEP have shown pulmonary edema and cardiac abnormalities, such as supraventricular and ventricular arrhythmias during epileptic seizures ${ }^{18}$. Schuele et al. reported an incidence of ictal asystole in $0.27 \%$ of patients submitted to video-electroencephalografic monitoring ${ }^{18}$ confirming a possible association between ictal events and cardiac dysfunction.

Others common cardiac abnormalities observed in patients with epilepsy and SUDEP are the lengthening of corrected QT cardiac repolarization time (QTc), alteration of $\mathrm{T}$ wave, bradycardia and increased QT dispersion ${ }^{17}$. Surges et al., studying 25 patients observed prolongation of QTc in $12 \%$ of them ${ }^{19}$. This finding may suggest that QTc interval may have a role in SUDEP ${ }^{20,21}$. QTc is higher in epileptic patients as compared to normal subjects, and it appears to be related to disease duration, particularly over the early history of disease. It is unrelated to patient age or recent reported seizure frequency $^{22}$ but may be triggered by interictal epileptiform discharges, suggesting that transient dysfunction of cortical networks can interfere with cardiac repolarization ${ }^{23}$.

Mutation in potassium channel genes (KCNQ1, $\mathrm{KCNH} 2, \mathrm{KCNE} 1$ and KCNE2) and sodium channel genes (SCN5A) has been related to neonatal seizures and long QT syndrome ${ }^{24}$ and over one third of referred cases of SUDEP were found to harbor a genetic arrhythmia-susceptibility mutation ${ }^{20,25}$. Physiologic changes of mutated channels causing seizures or cardiac arrhythmias are similar ${ }^{25}$. Also, FS is currently observed in patients with epileptic syndromes associated with genetic mutations in genes of sodium channels subunits as SCN1B, SCN1A and $\mathrm{SCN} 2 \mathrm{~A}^{26}$. Sodium channel mutations of the genes SCN1A, SCN1B and SCN2A had been reported in patients with generalized epilepsy and FS (GEFS+), an autosomal dominant epilepsy ${ }^{27,28}$, with some of these patients developing latter on temporal lobe epilepsy ${ }^{11,12}$. Hindocha et al. reported two cases of SUDEP in a family with typical GEFS+ and a novel mutation of SCN1A and raised the hypothesis of a unique mutation to be responsible for both epilepsy and sudden death ${ }^{10}$. Corroborating this theory is the finding that SCN1A gene products are present in various regions of the heart in animal studies ${ }^{29-31}$.

Up to now, studies suggest that acute FS do not trigger a SUDEP event, but it is not clear if a susceptibility to FS could be associated with a major risk of SUDEP in patients that developed chronic epilepsy. Corroborating this hypothesis, Kinney et al.$^{32}$ demonstrated a high incidence of FS history in children that suffered of sudden death, not related to epilepsy. SUDEP is the most important direct epilepsy-related cause of death and while the exactly mechanisms or set of factors involved on SUDEP occurrence are still not clear the principal effort in preventing SUDEP should be prompt and optimal seizure control, especially generalized convulsive seizures and identification of cardiovascular associated diseases ${ }^{33}$.

\section{REFERENCES}

1. Scantlebury MH, Heida JG. Febrile seizures and temporal lobe epileptogenesis. Epilep Res 2010;89:27-33.

2. Comission on Epidemiology and Prognosis, International League Against Epilepsy. Guidelines for epidemiology studies on epilepsy. Epilepsia 1993; 34:592-596.

3. Heida JG, Pittman QJ. Causal links between brain cytokines and experimental febrile convulsions in the rat. Epilepsia 2005;48:1906-1913.

4. Chungath M, Shorvon S. The mortality and morbidity of febrile seizures. Nat Clin Prac Neurol 2010;4:610-621.

5. Donner EJ, Smith CR, Snead OC 3rd. Sudden unexplained death in children with epilepsy. Neurology 2001;57:430-434.

6. Schuele SU, Widdess-Walsh P, Bermeo A, et al. Sudden unexplained death in epilepsy: the role of the heart. Cleveland Clin J Med 2007;74(Suppl 1): S121-S127.

7. Nashef L. Sudden unexpected death in epilepsy: terminology and definitions. Epilepsia 1997;38(Suppl):S6-S8.

8. Annegers IF. United States perspective on definitions and classifications. Epilepsia 1997;38(Suppl 11):S9-S12.

9. Tomson T, Nashef L, Ryvlin P. Sudden unexpected death in epilepsy: current knowledge and future directions. Lancet Neurol 2008;7:1021-1031.

10. Hindocha N, Nashef $L$, Elmslie F, et al. Two cases of sudden unexpected death in epilepsy in a GEFS+ family with an SCN1A mutation. Epilepsia 2008;49:360-365.

11. Shinnar, S. Prolonged febrile seizures and mesial temporal sclerosis (letter, comment). Ann Neurol 1998;43:411-412.

12. Duchowny M, Harvey AS. Pediatric epilepsy syndromes: an update and critical review. Epilepsia 1996;37(Suppl):S26-S40.

13. Scorza FA, de Albuquerque M, Arida RM, et al. Sudden unexpected death in epilepsy: are winter temperatures a new potential risk factor? Epilep Behav 2007;10:509-510.

14. Stollberger C, Finsterer J. Cardiorespiratory findings in sudden unexplained/ unexpected death in epilepsy (SUDEP). Epilep Res 2004;59:51-60.

15. Nashef L, Hindocha N, Makoff A. Risk factors in sudden death in epilepsy (SUDEP): the quest for mechanisms. Epilepsia 2007;48:859-871. 
16. Singh RB, Kartik C, Otsuka K, et al. Brain-heart connection and the risk of heart attack. Biomed Pharmacother 2002;56:257-265.

17. Surges R, Taggart P, Sander JW, Walker MC. Too long or too short? New insights into abnormal cardiac repolarization in people with chronic epilepsy and its potential role in sudden unexpected death. Epilepsia 2010;51: 738-744.

18. Toth $V$, Hejjel L, Fogarasi A, et al. Periictal heart rate variability analysis suggests long-term postictal autonomic disturbance in epilepsy. Eur J Neurol 2010;17:780-787.

19. Schuele SU, Bermeo AC, Alexopoulos AV, et al. Video-electrographic and clinical features in patients with ictal asystole. Neurology 2007;31;69: 434-441.

20. Surges R, Scott CA, Walker MC. Enhanced QT shortening and persistent tachycardia after generalized seizures. Neurology 2010;74:421-426.

21. Bell GS, Sander JW. Sudden unexpected death in epilepsy. Risk factors, possible mechanisms and prevention: a reappraisal. Acta Neurol Taiwan 2006;15:72-83.

22. Brotherstone R, Blackhall B, McLellan A. Lengthening of corrected QT during epileptic seizures. Epilepsia 2010;51:221-232.

23. Drake ME, Reider CR, Kay A. Electrocardiography in epilepsy patients without cardiac symptoms. Seizure 1993;2:63-65.

24. Tavernor SJ, Brown SW, Tavernor RM, Gifford C. Electrocardiograph QT lengthening associated with epileptiform EEG discharges: a role in sudden unexplained death in epilepsy? Seizure 1996;5:79-83.
25. Heron SE, Hernandez M, Edwards C, et al. Neonatal seizures and long QT syndrome: a cardiocerebral channelopathy? Epilepsia 2010;51:293-296.

26. Johnson JN, Hofman N, Haglund CM, Cascino GD, Wilde AA, Ackerman MJ. Identification of a possible pathogenic link between congenital long QT syndrome and epilepsy. Neurology 2009;72:224-231.

27. Nakayama J. Progress in searching for the febrile seizure susceptibility genes. Brain Dev 2009;31:359-365.

28. Scheffer IE, Berkovic SF. Generalized epilepsy with febrile seizures plus. A genetic disorder with heterogeneous clinical phenotypes. Brain 1997; 120:479-490.

29. Baruscotti M, Westenbroek R, Catterall WA, DiFrancesco D, Robinson RB. The newborn rabbit sino-atrial node expresses a neuronal type I-like $\mathrm{Na}+$ channel. J Physiol 1997;498:641-648

30. Marionneau C, Couette B, Liu J, et al. Specific pattern of ionic channel gene expression associated with pacemaker activity in the mouse heart. J Physiol 2005;562:223-234.

31. Haufe V, Cordeiro JM, Zimmer T, et al. Contribution of neuronal sodium channels to the cardiac fast sodium current INa is greater in dog heart Purkinje fibers than in ventricles. Cardiovasc Res 2005;65:117-127.

32. Kinney HC, Chadwick AE, Crandall LA, et al. Sudden death, febrile seizures, and hippocampal and temporal lobe maldevelopment in toddlers: a new entity. Pediatric Dev Pathol 2009;12:455-463.

33. So EL, Bainbridge J, Buchhalter JR, et al. Report of the American Epilepsy Society and the Epilepsy Foundation joint task force on sudden unexplained death in epilepsy. Epilepsia 2009;50:917-922. 